\title{
Introduction: Making Sense of Environmental Geography
}

DOI:

10.1002/9781444305722.ch1

Link to publication record in Manchester Research Explorer

\section{Citation for published version (APA):}

Castree, N., Demeritt, D., \& Liverman, D. (2009). Introduction: Making Sense of Environmental Geography. In $A$ Companion to Environmental Geography|A Companion to Environ. Geogr. (1st ed., pp. 1-15). John Wiley \& Sons Ltd. https://doi.org/10.1002/9781444305722.ch1

\section{Published in:}

A Companion to Environmental Geography|A Companion to Environ. Geogr.

\section{Citing this paper}

Please note that where the full-text provided on Manchester Research Explorer is the Author Accepted Manuscript or Proof version this may differ from the final Published version. If citing, it is advised that you check and use the publisher's definitive version.

\section{General rights}

Copyright and moral rights for the publications made accessible in the Research Explorer are retained by the authors and/or other copyright owners and it is a condition of accessing publications that users recognise and abide by the legal requirements associated with these rights.

\section{Takedown policy}

If you believe that this document breaches copyright please refer to the University of Manchester's Takedown Procedures [http://man.ac.uk/04Y6Bo] or contact uml.scholarlycommunications@manchester.ac.uk providing relevant details, so we can investigate your claim.

\section{OPEN ACCESS}




\title{
Chapter 1
}

\section{Introduction: Making Sense of Environmental Geography}

\author{
Noel Castree, David Demeritt and Diana Liverman
}

On the evening of Monday, 31 January 1887, Halford Mackinder delivered a now famous address to London's Royal Geographical Society. In his lecture - entitled 'On the scope and methods of geography' - he explained how and why geography should take its place alongside other disciplines within the academic division of labour. His strategy, at once simple and audacious, was to call that division of labour into question. Geography, Mackinder (1887) argued, can 'bridge one of the greatest of all gaps': namely, that separating 'the natural sciences and the study of humanity' (p. 145). He was not alone in defining geography as 'the science whose main function is to trace the interaction of man [sic.] in society and so much of his environment as varies locally'. At points east and west, others were doing much the same, such as William Morris Davis in America and Friedrich Ratzel in Germany. The three men soon occupied important university positions and were followed by similarly vigorous prosleytisers who quickly built on the foundations their forebears had laid.

So began geography's career as a university subject and what historian of geographical thought David Livingstone (1992, p. 177) called 'the geographical experiment'. A century on that experiment continues. Although space and region have since joined human-environment relations as central organising concepts for the discipline, many still see geography as the 'original integrated environmental science' (Marston, 2006). Geography remains one of the few disciplines committed to bridging the divide between the natural and physical sciences, on the one side, and the social sciences and humanities on the other. Quite how successful that bridging has been is a matter of some debate (see, for example, Matthews and Herbert's [2004] book Unifying geography). Despite the hopes invested by Turner (2002) and others (e.g., Marston, 2006; Zimmerer, 2007) in human-environment relations as the unifying link holding the discipline together, many geographers prefer to study other things. There is no shortage of 'pure' human and physical geographers. Even so, the scale and richness of geographers' attempts to understand the entanglements of people and the non-human world are highly impressive. These many geographers, their findings and their ideas are what we are calling here 'environmental geography' 


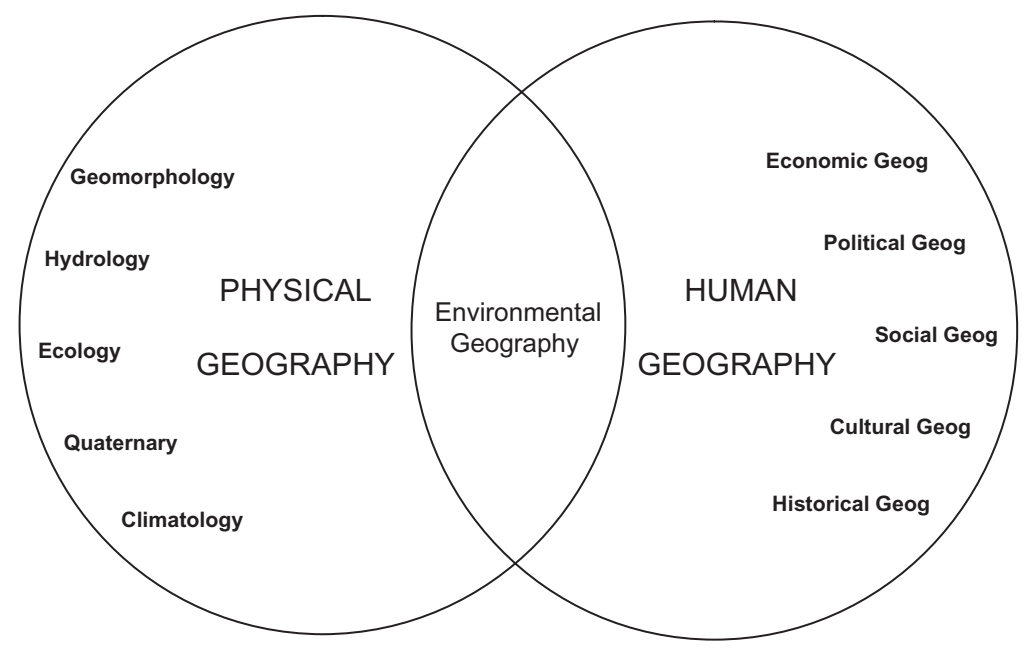

Figure 1.1 Environmental geography as disciplinary 'middle ground'.

(or what has sometimes also been called the 'human-environment' or 'man-land' traditions of geography'). By whatever name, environmental geography occupies the fertile 'borderlands' where geography's various traditions of scholarship - not only human, physical, but also regional and GIS - come together and connect with each other and with cognate traditions of environmental work outside geography (figure 1.1).

Though the term is perhaps less familiar than are 'human' and 'physical' geography, environmental geography deserves greater recognition both within and beyond the discipline. As this Companion is designed to show, environmental geography is much more than simply the residual intersection of geography's two halves. Environmental geography is a large, diverse and vibrant field of knowledge with few, if any, equivalents elsewhere in the conventional academic division of labour. The 32 chapters of this book will, we hope, offer readers both an incisive and accessible introduction to this field and set the agenda for its future development.

What makes this book distinctive is its catholic vision for environmental geography. There are now myriad texts focussing on human or physical geography respectively or some subfield thereof, including several previous Companions (see, for instance, Agnew et al., 2001). There are also now numerous volumes focusing on some specific approach to, or branch of, the study of human-environment relations, such as 'political ecology' (see, for instance, Robbins, 2004) or 'hazards geography' (see, for instance, Pelling, 2003). What is long overdue is a book that demonstrates the size, breadth and multiplicity of geographical work at the peopleenvironment interface. In short, the Companion casts its net far wider than most recent texts about one or other subfield of geography has been prepared to do. As a result, the book is not beholden to the now conventional view - among many geographers at least - that geography comprises two 'halves' and only a vanishing centre.

The volume has four parts: 'Concepts', 'Approaches', 'Practices' and 'Topics'. They comprise epistemic 'cuts' into the body of environmental geography, four ways 
of organising a wide-ranging set of contributions. In each case, authors were asked to address some specific issue or aspect of this broader terrain. Consequently, each chapter can be read alone and in no particular order since their authors were not instructed to formally situate their 'part' within a wider 'whole'. As even a quick glance at the chapter titles reveals, these parts together cover an enormous range of material and perspectives. We trust that this will make the Companion a lively, interesting and synoptic account of the field. Depending on your background and predilections, there will be material in this book that is (variously) familiar, surprising, challenging and even unsettling. Specialists will find insightful discussions of the 'state of the art' in specific conceptual, methodological and topical areas. Teachers should find the chapters to be useful pedagogical resources, while for students of geography and related fields, it offers accessible introductions to a wide range of key ideas, methods and debates. In all cases, the Companion aims to be as intelligible to readers with no geographic education as to those who have studied or practised geography for years. Indeed, a key claim of the book is that the field and discourse of environmental geography exceed the discipline of geography. At the same time, it is important to note that although the field of environmental geography is increasingly international in its scope and membership, our contributors hail largely, but by no means exclusively from the UK and North America. In part, this is a function of our own personal and professional histories of living, studying and working on both sides of the Atlantic. (The anglophone focus of this Companion partly reflects the barriers which need to be overcome to create a truly international environmental geography, although some contributions certainly acknowledge the considerable influence of non-English-speaking theorists and analysts of environment [in environmental discourses or development theory for example] and cite important international collaborative work [in land science for example].)

Rather than trying to summarise the contents of each and every chapter, we want instead to provide an overview of the wider landscape of research, practice and knowledge to which they contribute. As a result, the next three sections of this introduction are devoted to making sense of the complicated intellectual landscape that is environmental geography. There are a number of important and interesting issues to consider here, starting with definitional ones.

\section{Defining Environmental Geography}

The term 'environmental geography' is not one that most geographers to whom it could reasonably apply usually use to identify themselves or their work. Instead, geographers more typically imagine their discipline as one of two halves - human and physical. Within those two broad churches, there are numerous subfields, like economic geography or geomorphology, with which specialists identify. Although activity and interaction between human and physical geography (e.g., by geographers of 'natural hazards' and 'natural resources') is being increasingly acknowledged, through, for example, various conference sessions designed to speak across 'the divide' (e.g., Harrison et al., 2004), this dualism still dominates the organisation of the discipline in which Progress in Physical Geography is imagined as something separate from Progress in Human Geography (these names, for readers unfamiliar with them, refer to two leading geography journals).

This view of things may surprise non-geographers or pre-university geography students. After all, geography's public image is partly that of an 'integrative' disci- 
pline, while much of the subject's popularity in schools is due precisely to its focus on human-environment interactions. Yet the reality is that for most academic geographers 'environmental geography' is a small and often pretty elusive thing compared with the dominant human and physical wings of the discipline. (It may also be less familiar to North American readers where environmental geography has maintained more of a central role in some departments and topics, following for example, the traditions of human-environment geographers such as Carl Sauer or Gilbert White.)

One impetus for this book is to raise the profile of environmental geography both within and beyond the discipline. The environment is now widely touted as one important reason for 'Rediscovering Geography', to quote the title of a US National Academy of Sciences (1997) report on the future of geography. Echoing such calls, Billie Lee Turner (2002; cf. Zimmerer, 2007) is just one of a number of prominent figures urging geographers to embrace their long-ignored human-environment tradition so as to revitalise the discipline and secure its historically precarious place in the academy. Environmental geography, according to this way of thinking, provides a unifying link holding the two parts of the discipline together. It promises to make good on the integrative vision of geography celebrated by Mackinder, Davis and Ratzel but foiled as the discipline has become progressively more segmented and specialised since the Second World War.

While we certainly support those aspirations, they will only be achieved by overcoming three misconceptions about environmental geography. The first is about its place in the discipline of geography. Though environmental geography is often understood as a sort of middle ground between human and physical geography, this greatly oversimplifies the shape of the discipline and thus the problems we face in forging closer bonds of collective connection, collaboration and solidarity among its various parts and branches. Rather than thinking about geography divided horizontally between human and physical geography, we also need to recognise that the heterogeneity within those very broad divisions means they are also stretched out in the vertical dimension (figure 1.2), as indeed in a third temporal dimension of

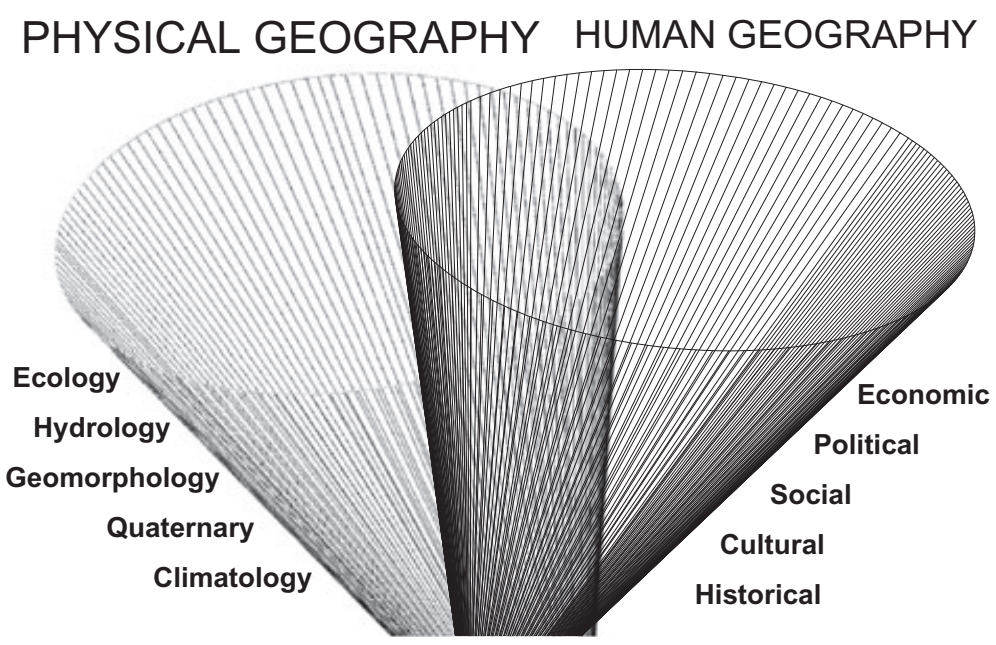

Figure 1.2 The multidimensionality of disciplinary divides in geography. 
time. The implications of this verticality are several. First, the vertical gaps within human geography between, say, modellers of land-use change and various postnatural theorists of the environment can be even more yawning than the putative human-physical divide. But second, acknowledging this verticality also implies that there ought to be many more potential points of contact than is suggested by the simplistic ideas of environmental geography as some kind of halfway house between human and physical geography. (Third, it indicates the multiple points of possible connections with other disciplines and communities.)

The second misconception stems from this first one. Seeing environmental geography as the mid-point of a one-dimensional divide between human and physical geography leads to a very narrow definition of what environmental geography is and ought to be. Implicit in many geographers' thinking today - so implicit that it is now arguably part of geographical lore - is the idea that only a fully 'symmetrical' approach to human-environment relations counts as 'real' environmental geography. By symmetrical we mean an approach that pays equally detailed attention to both people and non-humans as they interact. For instance, a symmetrical approach to the study of a new urban greenspace would need to account for how this patch of country in the city sustains migratory and local wildlife, reduces surface rainfall runoff, moderates solar radiation and so on, but it would also need to examine how people perceive and use this greenspace, taking care to differentiate age, gender, ethnic groups and so forth, while also considering issues of leisure as well as crime.

Historically, this kind of symmetrical understanding of human-environment relations was achieved and embodied by the individual geographer. Indeed, Mackinder made little distinction between individual geographers and the wider discipline they comprised. For him the integrative role as bridge between the natural and social sciences applied equally to both. But specialisation within the sciences, along with the exponential increase in the stock of scientific knowledge, has meant that even at the smallest geographical scale, this kind of all-encompassing and fully symmetrical account of human-environment relations is very difficult, if not impossible for any one individual to achieve: it requires broad expertise and a great deal of time if it is to be done well. Furthermore, the sorts of integrative and symmetrical understandings that individual geographers could provide also run the risk of being dismissed by specialists as trivial for failing to advance knowledge in more narrowly defined areas of research. For all these reasons, few geographers even try to achieve fully symmetrical understandings ideal typically associated with environmental geography.

One response to this dilemma is to relocate the sites for symmetrical environmental explanation to the level of discipline or research programme. When Marston (2006) refers to geography as the 'original integrative environmental science', the claim is not about the knowledge of individual geographers but about the potential of the discipline as a whole to bridge the divides between the various kinds of specialist expertise germane to understanding human-environmental relations. Similarly, many science-funding agencies are now looking to support large, multicomponent research programmes that bring together the different sorts of specialist expertise to address the pressing problems of our times. Because the discipline of geography combines specialists from both sides of the divide who ideally have had some undergraduate-level training in both human and physical geography, geographers ought to be well placed to respond to environmental initiatives like 
the ongoing Rural Economy and Land Use (RELU) of the UK Research Councils (www.relu.ac.uk) (or the calls for integrative environmental research initiatives within the EU or US National Science Foundation). However, as the development of Earth System Science (see Wainwright, this volume) shows, the discipline of geography has not always profited from such initiatives.

This is at least partly because the lingering hold of Mackinder's normative vision of geographical knowledge as fully symmetrical has been so great that we have not always recognised the valuable contributions to be made by the profusion of 'asymmetrical' environmental research evident within geography today. By this term, we mean research and teaching that stitches together separately fashioned pieces of the human-environment jigsaw. People and the non-human world are connected in a multiplicity of ways; there are varying degrees and kinds of interactions, associations, couplings, feedbacks, interferences, transformations and accommodations going on. It is perfectly possible - and for a variety of reasons defensible, even necessary - to examine human-environment connectivities in 'asymmetrical' ways. For instance, physical geographers who are expert in river restoration may go about their work without having to know why certain social groups like restored rivers or why government planning regulations prohibit more restoration projects from occurring. Likewise, the 'Third World political ecologist' can say important things about how and why peasant farmers use their land in the ways they do, without having to know all the biological intricacies of crop rotation, soil fertility and plant germination.

This book is mostly about environmental geography in this asymmetrical sense - which is to say, the form in which it predominantly exists today. This does not, as we are suggesting, make the research reported in its many chapters an ersatz version of 'symmetrical' environmental geography. The latter has become a hardto-achieve and highly normative ideal that many geographers have, understandably, found of little use to describe their own and others' work. In our view, the expanded definition of environmental geography that we are working with here - namely, any form of geographical inquiry which considers formally some element of society or nature relative to each other - is usefully open-ended. It opens up a much broader landscape of shared knowledge and practice, whose richness and potential only becomes apparent once we shake off the older vision of environmental geography as necessarily symmetrical.

This more expansive sense of environmental geography highlights a third misconception about environmental geography, namely that it is confined to the discipline of geography. Environmental geography bleeds into other disciplines and fields that share its interest in 'the geographical experiment' (and human environment interactions). As noted above, we can formalise both points by drawing a distinction between the 'discipline' of environmental geography and a wider discourse that goes beyond it (cf. Gregory, 1995). This includes specialised fields like environmental sociology and environmental economics, as well as relatively young, purposefully cross-disciplinary fields like environmental science, 'science studies', 'environmental studies' and the already mentioned Earth Systems Science. Unsurprisingly, little of the work done in these and cognate fields uses the term 'environmental geography'. But it does share the same commitment to investigating the social and non-human worlds in relation to one another (albeit 'asymmetrically' in many cases). On the social sciences side of all this, something of the scale and diversity of the discourse of environmental geography is captured well in Pretty et al.'s (2008) recent Hand- 
book of Environment and Society. (And on the science side, a series of reports by the US National Research Council on sustainability, human dimensions of global change and common property resources acknowledge the value of engaging the social sciences [www.nrc.edu].)

While fairly definite, the borders that demarcate geography from these various other fields in the wider discourse of environmental geography are sufficiently porous that two-way traffic occurs quite readily, as many of our chapters bear out. In some cases, environmental geographers feel as much part of these other fields as their own. In other cases, they either draw upon the other fields to make their own distinctive contributions or else seek to shape them by 'exporting' their particular skills, perspectives and insights. Whatever the 'terms of engagement', an important common denominator applies here: most environmental geographers happily see themselves as part of a wider project, which they can learn from and shape. Today, 'the geographical experiment' is far, far more extensive than Mackinder could have possibly envisaged. Indeed, one might argue that there has never been more interest in the study of human-environment relations - from students, publics, states, firms and a range of other stakeholders - than there is today.

Geography, it is fair to say, does not occupy centre stage in the wider discourse of environmental geography. No one subject does. This fact might well have disappointed Mackinder, but if he were alive today, we would suggest to him that centrality is not the issue. Far more important is that environmental geographers are able to contribute distinctive and significant things to researchers, teachers, students and other stakeholders involved in the wider discourse.

\section{Environmental Geography: Unity and Difference}

Having loosely defined environmental geography, some further questions arise. What, it may be asked, is to be gained by abandoning the narrow, normative 'symmetrical' definition of the field and embracing a broader, more inclusive one? The answer to this question depends upon us answering another: namely, what do environmental geographers - ecumenically defined - have in common? Some obvious answers come immediately to mind.

First, as per our enlarged definition of environmental geography, they all study some aspect of society or nature in relation to one another rather than alone. They all take as axiomatic David Harvey's (1996) observation that 'all social ... projects are ... projects about environment, and vice versa' (p. 189). Second, they are all engaged in discussion about the character, purpose, meaning and proper management of these socio-natural relations (in peer review journals, edited books like this one, monographs, textbooks, lectures, seminars, policy briefs, etc.). These discussions involve various semantically rich terms, metaphors and analogies - such as 'dependent' and 'independent' variables, cause and consequence, condition and outcome, feedback and perturbation, hybrid actants, dialectical contradiction, force and resistance, co-constitution, and so on. Third, the specific knowledge claims in question are produced largely by professionals who regard it as their job - an occupational objective - to produce them. In other words, the discourse of environmental geography is not generated by accident or happenstance but intentionally and as a formal, full-time pursuit. Fourth, and relatedly, this knowledge has the specific qualities of all academic discourse: namely, it is derived from disciplined thought and inquiry, is somewhat (or very) esoteric, and commands a certain authority from 
students and others dependent on academic expertise. Put differently, the discourse of environmental geography is not colloquial, tacit or everyday. In the fifth place, whether couched in 'realist' or more 'constructivist' language, the claims advanced by environmental geographers are intended to tell us something about the actualities (today, yesterday or tomorrow) of human-environment relations. It is - at least usually - the opposite of science fiction, ungrounded speculation or metaphysics, a feature very much in keeping with geography's long-standing reputation as a 'practical' discipline that has its feet firmly on the ground. Finally, as all the chapters of this book make clear and as we have had already noted, environmental geographers of all stripes are intellectually outward-looking. They draw upon (and seek to contribute to) debates in cognate fields in both the social and the biophysical sciences, as well as in the humanities (see, e.g., the chapters by Zimmerer, Mels, Olwig, Turner, and Jones).

These various commonalities are real enough, but they may - understandably strike many readers as being far too generic to define a real, as opposed to a contrived, field of research, teaching and practice. Indeed, the final commonality mentioned above may appear to render questionable the very idea of 'environmental geography' since the field routinely blurs into so many others as to lack any defining features of its own. Not surprisingly, we beg to differ with this rather dim assessment. True, environmental geography is diverse and lacks coherence philosophically, theoretically, methodologically and in terms of its practical applications. Its exponents produce an array of cognitive, evaluative, expressive, methodological and applied knowledges; and they vary greatly in the spatio-temporal scale and topical foci of their concern. Whatever unity environmental geography possesses is, pace the six commonalities listed above, certainly quite general. However, the field's diversity is nonetheless a structured one and we regard the heterodoxy of environmental geography as a strength not a weakness. Let us explain.

Even though environmental geography - like the wider discipline of which it is a major part - does not posses the sort of 'hard' external boundaries one finds in, say, the discipline of economics, it nonetheless has a very real identity - a 'structure of feeling' in Raymond Williams' evocative but nonetheless definite sense of the term. Over a century on, the legacy of Mackinder, Davis, Ratzel and like-minded pioneers is tangible: Geography remains one of the few places where it is possible to find social science, humanities and physical science perspectives on the environment rubbing shoulders. In other words, academic geography is constituted so as to permit something that one still finds rarely elsewhere: namely, a 'full spectrum' approach to understanding human-environment relations, albeit in the form of separate, asymmetrical contributions. For this reason, geography is 'recognized as possessing unusual strength in integrated, human-environment science' (Turner, 2002, p. 63). Compare this with, say, earth science (which excludes the human factor) or sociology (which has 'rural' and 'environmental' branches but both of these bracket biophysical issues for the most part).

This internal permissiveness - this encouragement and toleration of widely divergent research, teaching and policy work on human-environment relations - can be regarded as a virtue. This may seem counter-intuitive. Typically, the ongoing debates about the (dis)unity of geography as a whole depicts intellectual diversity as synonymous with fragmentation, and thus, intellectual weakness. This much is obvious in the book Unifying Geography, whose normative, aspirational title speaks to the editors' desire to reconnect the discipline's many (in their eyes) amputated limbs. 
However, underlying such a negative judgement about disunity are some questionable presumptions that are not always made manifest. One is that there is a single reality 'out there' that demands an intellectual and practical approach able to respect its integrity. Another, relatedly, is that otherwise different perspectives on the world can ultimately be commensurated and synthesised (perhaps via a meta-language like 'complexity theory'). The idea that there might be multiple realities and/or a range of legitimately different perspectives on them is barely entertained. As sociologist of knowledge Tim Dant (1991) once noted, 'We tend to live as if knowledge could be settled, as if there is only one true knowledge we are striving for' (p. 1, emphasis added).

This belief reflects the enduring power of the idea of 'science' in the 21st century. In William Whewell's (1794-1866) original sense, 'science' simply meant any form of systematic inquiry undertaken according to a procedure that suitably qualified others that could replicate or validate. However, over time, the term has become polysemic, signifying (among other things) a form of 'objective inquiry' into a world that exists independently of the inquirer and whose 'real' properties can be correctly understood given time and adequate resources. Geography's enchantment with science in this specific sense was most intense between the mid-1950s and mid1970s. Somewhat diminished, it nonetheless continues to this day, notably in most branches of physical geography, some parts of human geography and in elements of environmental geography too. The commitment to science conceived thus has a 'strong' and a 'weaker' form. The former (which few environmental geographers or, indeed, any geographers would publicly defend) supposes that there is only one 'true method' for interrogating reality: namely, 'the scientific method', which would today be understood practically as a form of hypothesis testing (or problem-solving) using melange of inductivism, deduction, inference, retroduction, verification and falsification depending on the case. The latter ('weak scientism') is a modern version of Auguste Comte's (1798-1857) Enlightenment conception of human knowledge as a giant jigsaw puzzle, the pieces of which can be identified by different disciplines and sub-disciplines and ultimately pieced together. It supposes that there may be different ways of deriving true knowledge, but that these knowledges (once derived) can be married together on the grounds that reality is continuous not partitioned into the mental boxes we typically use to comprehend it.

The commitment to science in either of these forms cannot be dismissed, even after several decades of questioning the whole idea that science $=$ truth (or at least the quest for truth). However, our own view - and that of environmental geographers as a whole, if this book is anything to go by - is that 'science' is in fact plural and, thus, best seen as one approach to, and form of knowledge, among many rather than a privileged or Archimedean one. To argue otherwise entails suggesting that 'non-scientific' forms of knowledge are less valid and that reality is, ontologically speaking, singular and consistent rather than discontinuous, differentiated and stratified. There is also the questionable implication that science is value-free. ${ }^{1}$

In this light, we might look favourably upon the 'multi-paradigm' condition of environmental geography (and note too that many other fields of knowledge in the humanities, social sciences and humanities are today similarly heterodox). The field's astonishing intellectual diversity can, perhaps, be seen to reflect a very important fact: namely, that a topic as broad as 'human-environment' relations simply cannot be understood through one - let alone one putatively 'objective' - approach, worldview or method. You do not have to be an epistemic 'conventionalist' or 
'nominalist' to acknowledge this fact, let alone a 'relativist'. One can happily insist that there is a 'real world' out there, while still conceding that it is sufficiently complex and differentiated such that no one mode of knowing it will suffice for all our wishes and purposes. (Even traditions of environmental modelling can approach the same question using very different assumptions about human behaviour and societal dynamics, and reflect different approaches to explaining atmospheric or ecosystem dynamics.) In short, environmental geography's diversity should not be sacrificed on the altar of 'unity' - or least not the sort of 'strong' unity that presumes epistemic variety to be symptomatic of intellectual confusion about the 'true' nature of human-environment relations.

This said, our reluctance to define environmental geography in terms of the narrow and highly normative standard of symmetry does not mean that we are agnostic about its current condition. On the contrary, we believe some positive change is required. There is one obvious problem with a 'let many flowers bloom' stance towards the field. It is not so much a problem of epistemic relativism - as we have explained, there is no consensus about whether we can know reality independently of our various mental and physical engagements with it as researchers. Instead, it is more a problem of mutual ignorance and indifference. This risk was identified many years ago for geography as a whole by John Pickles and Michael Watts. As they put it, the '... unwillingness to debate the merits of competing frameworks encourages reliance on values: assertion, training and faith become sufficient conditions for selection. A new [plural] dogmatism is asserted...' (Pickles and Watts, 1992, p. 303). What they were calling for was the development of a critical culture within the discipline. Nominally at least, environmental geographers share a common object of analysis and concern: 'the environment'. While there will always be real limits to communication to do with the sheer inability of one group of environmental geographers to understand what other equally specialised groups are 'up to', there is nonetheless room for greater cross-group dialogue and critique.

What would be the virtues of this and how might it be engendered? We can answer the first part of this question by analogising environmental geography to a nation state composed of highly diverse populations - think the USA, Britain or Australia, for example. A monocultural polity environmental geography is not. So is it, in analogical terms, a multicultural or a republican one? In our view, it is currently multicultural when it ought to be far more republican. What does this mean? We are using the term multicultural here (contentiously, we admit) to denote different ways of life that are spatially juxtaposed but which ignore or talk past one another. Some might call this 'communitarianism'. 'True' republicanism, by contrast, corresponds to what philosopher of science Karl Popper (1945) famously called 'the open society'. In Popper's view, all knowledge claims - along with their practical consequences - are only robust once they have withstood, been modified by, or enriched through an encounter with criticisms issuing from various quarters. Republicanism in knowledge (as in politics) ought to involve a genuine engagement between rival perspectives on the basis of common sensibilities - not so much to reduce epistemic differences in the name of 'one truth' but, instead, to ensure the socio-practical robustness of otherwise divergent knowledge claims.

The sort of open, critical culture being described here is difficult to engineer. It is underpinned by an ethic of responsibility rather than (pace Fuller, Pickles and Watts) an ethic of conviction, one that many or most members of any given academic discipline would need to share. It entails both mutual recognition and respect 
between the parties who might stand to gain through an epistemic encounter. Though environmental geographers, like geographers writ large, would find it far easier to continue with business as usual, it would nonetheless be far more possible (and desirable) to create an 'epistemic republicanism' within a generation than it would be to create the sort of 'strong' intellectual unity and 'symmetrical' environmental geography we have already discussed. Quite how one does this practically speaking remains uncertain. It would doubtlessly require a small number of respected intellectual leaders to set an example, along with a strong steer from professional associations like the Association of American Geographers and from academic journal editors too. It would also likely occur most readily by otherwise different researchers communicating about shared and specific topical concerns or problemsets, such as water management, animal conservation and climate change.

Fortunately, we are not entirely bereft of precedents and current examples of critical engagements between various strands of environmental geography. The sheer diversity of environmental geography has presented researchers and teachers with the possibility (if not the obligation) of becoming critical and creative synthesisers. Contrast this with a discipline like economics, where intellectual plurality is not tolerated nearly so much. In other words, the plain lack of orthodoxy in environmental geography as a whole has arguably made it easier for certain individuals to avoid encampment in one of other of its subfields. Think of Third World political ecology, which is a critical synthesis and application of a plethora of otherwise different concepts, methods and approaches. Think of 'new resource geography', which often combines neo-Marxist, institutionalist and Foucauldian concepts to make sense of modern mining or forestry.

\section{Environmental Geography in the 'Knowledge Society'}

Most environmental geography, as this book's contents attest, is produced in universities by professional academics. While the discipline and discourse of environmental geography are not entirely academic - (researchers and) non-academics in the environmental movement, for example, contribute richly to the discourse (see Porritt [2005], for instance) - they are largely so. Though a seemingly banal observation, it actually strikes us as being quite important. To understand why, we need to consider the meaning of the now-familiar term 'the knowledge society'.

As Fuller (2002) wryly notes, '. . . saying that we live in a 'knowledge society' would seem to be no more informative than saying that we live in a 'power society' or a 'money society'...' (p. 2). However, the term has a more precise meaning that is associated variously with commentators like Peter Drucker, Daniel Bell and Manuel Castells. In this more specific sense, the term denotes two distinct but related shifts in knowledge that were initially characteristic of the advanced capitalist economies but which are now more widespread. The first is a deliberate move to increase the range and volume of formal (as opposed to tacit) knowledge, something coincident with its intensified modularisation (as in the proliferation of software systems that can perform specific functions; as in the profusion of different databases, and so on). Second, 'the knowledge society' refers to an equally deliberate move to put this knowledge to work in a variety of ways as a means, an end or both - not the least of which is to make money ('commodified knowledge', such as patented gene codes). In this second sense, knowledge is not a goal in itself but, instead, a medium for realising particular ends and an instrument for action. 
If, in even only a general sense, the idea of a knowledge society holds good, then it obliges us to look again at the functions of the university as well as the wider context in which it now operates. Historically, as Bjorn Wittrock (1985) has argued, there are three models of the university operative in the West (archetypes if you will), and in all cases the university held a virtual social monopoly on the creation and dissemination of canonical as well as new formalised knowledge. In the British model, the post-medieval university aimed to create the 'well-rounded' or 'whole' person; in the French model, higher education was, as per Napoleon I's intentions, geared to the national interest; finally, in the German, Humboldtian model, universities are geared to the pursuit of pure understanding. In the late 20th century, there is plenty of evidence to suggest that Western universities have, en masse, moved closer to the archetypal French model. They have, according to one line of criticism, become 'corporatised' and very mindful of their contributions to 'national competitiveness' and 'the public interest'. At the same time, it is clear that the near monopoly that universities once held on the creation and dissemination of canonical, as well as new, formalised knowledge has been challenged. Today, research and teaching at a high level goes on, variously, in think tanks, foundations, non-governmental organisations, charitable bodies, colleges funded by benefactors, large firms and so on.

What has all this got to do with environmental geography? A good deal. Because of its intellectual breadth, environmental geography - like its parent discipline - has, historically, been able to meet the demands of all three models of the university. Importantly, its inability to be disciplined by the demands of any one of these models explains why, along with some other university subjects, it has been able to resist current pressures to make universities 'relevant' in a fairly instrumental sense. The knowledge that geographers produce, teach and disseminate outside the university remains sufficiently diverse that, while the latter pressures can be accommodated, they do not 'skew' the discipline unduly.

Skewing presents real dangers to any field. If, through financial or other levers, a discipline is steered heavily by outside interests, then there is the strong possibility exists for a reduction in epistemic diversity and the rise of new paradigms in Kuhn's original, subject-wide sense. The possibilities are already evident in so-called 'big science', where huge resources are being channelled into certain lines of inquiry but not others courtesy of biotechnology, biomedical, energy and pharmaceutical firms - sometimes aided by national governments. But similar pressures are also on the horizon (perhaps already here) for those disciplines that study humanenvironment relations. The sort of 'land change science' discussed in Billie Lee Turner's chapter is exciting, as are the closely related fields of 'earth system science' and 'sustainability science'. (Similarly, the growing focus on payments for environmental services, which engages many physical geographers in the measurement of such services, can too easily become the servant of a naïve market environmentalism.) But they could, in time, become the focus of enormous intellectual and fiscal inputs as societies become increasingly alarmed about global environmental change. In the USA, we have already seen the Global Change Research Program (created in 1990) become one of the largest ever foci of public research funds in American history. As currently constituted, environmental geography's plurality can make it a player in such grand endeavours yet without sacrificing its capacity to offer multiple insights and perspectives on human-environment relations. Indeed, environmental geographers were key players in the creation of the current 'global 
environmental change' research agenda going back 20-plus years. This bespeaks an admirable capacity to set their sites on big agenda issues, while refusing to be corralled into intellectual orthodoxies of a theoretical, methodological or policypolitical kind.

It is no accident that environmental geography's diversity and vitality is coincident with its basis in the university system. Despite being subject to varying degrees of 'corporatisation', Anglophone universities remain, for the most part, publicly funded and public in their identities. Though managerialism has, to some extent, eroded its potency, 'academic freedom' remains a critical ideal and reality for researchers, teachers and consultants based in university geography departments so too for all those other academics whose work constitutes the 'discourse of environmental geography'. A reflection of the relative autonomy of academics from outside interests and their historical claim to self-government, such freedom is precisely what - even today - allows environmental geographers and those working in cognate fields to determine how and why they will do the work that they do. Contrast this with knowledge producers and disseminators working in the 'knowledge society's' many other institutions, like think tanks, privately funded foundations (and even NGOs). In these institutions, the sort of environmental knowledge created is very much determined by the specific agendas of patrons, benefactors, shareholders and owners. This does not render it illegitimate of course. But it does circumscribe its likely interest and relevance to the enormous array of people and groups who have some stake in the drama - as well as the quotidian course - of humanenvironment relations.

This raises some critical questions about who is authorised to produce and validate particular sorts of environment-society knowledge today. In relation to the so-called 'expert' knowledge, the days of ivory-tower elitism are thankfully behind us. Universities are no longer recognised as being dispensaries of indisputable truth and wisdom. But they still play a vitally important role in our 'knowledge societies'. There is much debate about the nature of this role and how it might be sustained or altered. One well-known view is that academic experts 'enter the fray' as part of a new epistemic condition that Michael Gibbons and colleagues (1994) termed 'mode 2 knowledge'. 'Mode 1' knowledge has, historically, been produced by those (like academics) inhabiting a few 'authorised' institutions. By contrast, a mode 2 society (in Gibbons et al.'s view) is one where many knowledge workers in a range of sites come together to create robust knowledge about issues and problems of common concern (like climate change). This mode 2 way of operating is not beholden to old expert-lay distinctions and nor is it interested in the preservation of academic disciplines - unless the members of those disciplines can contribute meaningfully to the many, changing epistemic collectives that produce mode 2 knowledge.

In contrast to this vision of where universities sit within a wider knowledge society, others suggest that we update older ideas of academic expertise and nonpartisanship. For instance, in his book The Governance of Science, Steve Fuller (2000) suggests that universities are becoming 'clearing houses' for the airing, testing and encounter between diverse knowledges. In his view, basic and applied research should in future be undertaken outside universities in all those other institutions mentioned earlier in this section. The role of university experts is then, in his view, to scrutinise these knowledges according to an array of criteria (cognitive, moral, aesthetic, etc.). These experts will not seek to eliminate knowledges on the grounds of their 'falsity'. Instead, they will undertake both 'translation work' 
(making apparently incommensurable knowledges speak to one another) and check for the 'robustness' of knowledge (i.e., can it be made meaningful to a wide array of stakeholders or not?).

These and other views on the future of the university and its disciplines matter greatly for environmental geography and cognate fields. 'The environment' and the way humans use it is of such widespread and fundamental social importance that the creation, validation, disputation and circulation of human-environment knowledge will become ever more important for ourselves and the future of the biophysical world. To date, practitioners of environmental geography have gone about their research largely unmindful of the big debates on the university and the knowledge society. Looking to the future, this ought to change for the simple reason that the institutional and social context of knowledge production profoundly affects its content and aims. There is no 'context-free' knowledge and the precise role that environmental geographers play in wider epistemic debates on human-environment relations in academia and society will depend almost entirely upon how the university (re)defines itself as an institution.

\section{Conclusion}

This book is by no means an exhaustive introduction to environmental geography. For various reasons, certain things were left out (e.g., the Approaches section would have benefited from chapters on 'urban political ecology' and 'environmental restoration'). So this could have been a much larger, more comprehensive volume. Even so, it offers a fairly complete sense of what environmental geography currently is. In so doing, this book - and our attempt in this introduction to explain its aims - will, we hope, remind professional geographers that the 'middle ground' is not nearly as small as Mary often think it to be, while showing other readers outside geography that the discipline offers a virtually unique suite of theories, approaches, investigative methods and substantive insights into human-environment relations. As we have explained above, environmental geography does not 'represent itself': rather, it needs actively to be made sense of given the apparent dominance of geography's two halves. We hope very much that this book helps environmental geography to be seen by readers as what many of our contributors already regard it as being: that is, a major area of activity, at least equal in size and significance to human and physical geography, respectively.

This book, with its expansive sense of environmental geography, clearly says much about how 'the geographical experiment' is currently being conducted, and we in this introduction have suggested how it might be altered in years to come. It almost goes without saying that this experiment needs to continue on into the future and to have a proper institutional home in universities and other research, teaching and policy environments. Geography remains one important place for investigations of human-environment relations to be undertaken and communicated, though not the only one. It ultimately matters not where and under what banner such investigations occur. What is far more important is that societies continue to properly fund and resource them. After all, even in our supposedly digital, post-industrial, knowledge-intensive, 'weightless', information technology era, all of us draw upon the non-human world ineluctably as fleshy, emotional, thinking and acting beings. Current worries about the nature and impacts of 'global environmental change' are only the most dramatic reminder of this fact. 
We will never not need cognitive, moral, aesthetic and applied knowledge about how we currently (and ought in the future to) interact with the non-human world. Such knowledge covers a wide spectrum of functions and uses, such as problem solving (how can we reduce soil erosion?), moral guidance (what shared values might underpin global environmental accords?), the satisfaction of curiosity (how do wild animals adapt to urban life?) and much more besides. In humanity's various attempts to engage with the biophysical world materially and imaginatively, the sort of diverse, high-level inquiries reported here will be vital tools. In our capacity as citizens, workers, family members, tourists, activists, local residents and any number of other roles, we surely need the sort of research, teaching and policy knowledge that environmental geography offers alone and as part of a wider, societal discourse.

\section{NOTE}

1. These arguments and the counter-arguments to them were aired not altogether productively in the so-called 'science wars' of the late 1990s in the USA. See Ashman and Baringer (2001) for a post-mortem.

\section{BIBLIOGRAPHY}

Agnew, J., Mitchell, K. and Toal, G. (eds) (2001) A Companion to Political Geography. Oxford: Blackwell.

Ashman, K. and Baringer, P. (eds) (2001) After the Science Wars. New York: Routledge. Dant, T. (1991) Knowledge, Ideology and Discourse. London: Routledge.

Fuller, S. (2000) The Governance of Science. Buckingham: Open University Press.

Fuller, S. (2002) Knowledge Management Foundations. Woburn: Butterworth-Heinemann. Fuller, S. (2003) Popper vs Kuhn. Cambridge: Icon Books.

Gibbons, M. (1994) The New Production of Knowledge. London: Sage.

Gregory, D. (1995) Geographical Imaginations. Oxford: Blackwell.

Harvey, D. (1996) Justice, Nature and the Geography of Difference. Oxford: Blackwell.

Harrison, S., Massey, D., Richards, K., Magilligan, F. J., Thrift, N. and Bender, B. (2004) Thinking across the divide: perspectives on the conversations between physical and human geography. Area, 36, 435-42.

Livingstone, D. (1992) The Geographical Tradition. Oxford: Blackwell.

Mackinder, H. (1887) On the scope and methods of geography. Proceedings of the Royal Geographical Society, 9, 141-60.

Marston, R. (2006) Geography: the original integrated environmental Science. Presidential Plenary address to the Association of American Geographers, 8 March, Chicago, IL.

Matthews, J. and Herbert, D. (eds) (2004) Unifying Geography. London: Routledge.

Pelling, M. (ed.) (2003) Natural Disasters and Development in a Globalizing World. London: Routledge.

Pickles, J. and Watts, M. (1992) Paradigms for inquiry? In R. Abler, M. Marcus and J. Olson (eds), Geography's Inner Worlds. New Brunswick: Rutgers University Press, pp. 301-26.

Popper, K. (1945) The Open Society and Its Enemies London: Routledge \& Kegan Paul.

Porritt, J. (2005) Capitalism as if the World Matters. London: Earthscan.

Pretty, J., Ball, A.S., Benton, T., Guivant, J., Lee, D.R., Orr, D., Pfeffer, M. and Ward, H. (eds) (2008) The Sage Handbook of Environment and Society. London: Sage.

Robbins, P. (2004) Political Ecology. Oxford: Blackwell.

Wittrock, B. (1985) Dinosaurs or dolphins? In B. Wittrock and A. Elzinga (eds), The University Research System. Buckingham: Open University Place, pp. 13-38. 
